\title{
Correlation Between Blood Glucose and Estradiol Levels in Women in Reproductive Age
}

\author{
David Lionardi, ${ }^{1}$ Chrismis Novalinda Ginting, ${ }^{2}$ Linda Chiuman ${ }^{3}$ \\ ${ }^{1}$ Master Program of Biomedical Sciences, Universitas Prima Indonesia, Medan, North Sumatera, Indonesia, \\ ${ }^{2}$ Faculty of Public Health, Universitas Prima Indonesia, Medan, North Sumatera, Indonesia, \\ ${ }^{3}$ Faculty of Medicine, Universitas Prima Indonesia, Medan, North Sumatera, Indonesia
}

\begin{abstract}
Type 2 Diabetes mellitus (Type 2 DM) is a metabolic disorder characterized by an increase in blood sugar caused by decreased insulin secretion by pancreatic beta cells and/or impaired insulin function (insulin resistance). This study aimed to determine the specific levels of estradiol hormone in reproductive age women with diabetes mellitus in different age groups. This was an analytical study in September at Royal Prima Hospital, North Sumatra, Indonesia. Twenty women participated in this study after informed consent and were divided into two age groups: 40-45 years old and 46-50 years old. Blood samples were collected after 10-12 hours of fasting to assess blood sugar and estradiol hormone levels. Data were then analyzed using the dependent t-test dependent and compared. No significant difference in blood sugar level was found between the two age groups ( $\mathrm{p}$-value $=0.113$, $\mathrm{p}$-value $>0.05$ ) that there were no significant differences in blood sugar levels between the two age groups. The estradiol hormone level in the age group 40-45 years was lower than in the age group 46-50 years, and the difference was significant ( $\mathrm{p}$-value $=0.000$, $\mathrm{p}$-value $<0.05$ ). No significant correlation was seen between type $2 \mathrm{DM}$ and estradiol hormone level in this study. In conclusion, age is not the main contributing factor for the increase and decrease in blood sugar level, and type 2 DM does not correlate with estradiol hormone.
\end{abstract}

Key words: Estradiol level, hormone, type 2 diabetes mellitus

\section{Hubungan Antara Kadar Glukosa Darah dan Kadar Estradiol Pada Masa Reproduktif}

\begin{abstract}
Abstrak
Diabetes melitus (DM) Tipe 2 adalah penyakit gangguan metabolik yang ditandai oleh kenaikan gula darah akibat penurunan sekresi insulin oleh sel beta pankreas dan atau ganguan fungsi insulin (resistensi insulin). Penelitian ini bertujuan mengetahui kadar hormon estradiol wanita reproduktif yang menderita diabetes mellitus pada kelompok usia yang berbeda. Penelitian ini merupakan penelitian analitik yang dilakukan pada September 2019 di Rumah Sakit Royal Prima, North Sumatera, Indonesia. Sebanyak 20 wanita berpartisipasi dalam penelitian ini setelah mendapat persetujuan dan dibagi atas dua kelompok usia, 40-45 tahun dan 46-50 tahun. Sampel darah diambil setelah 10-12 jam puasa untuk menilai kadar gula darah dan hormon estradiol. Data kemudian dianalisis menggunakan t-test dependent dan dibandingkan. Tidak terdapat perbedaan kadar gula darah antara kedua kelompok usia ( $\mathrm{p}=0.113$; $\mathrm{p}>0.05$ ) sehingga tidak ada perbedaan kadar gula darah yang bermakna. Kadar hormon estradiol pada kelompok usia 40-45 tahun memiliki kadar estadiol lebih rendah dibanding dengan kelompok usia 46-50 tahun. Tidak terdapat korelasi antara DM tipe 2 dan hormon estradiol yang bermakna pada penelitian ini. Simpulan, bahwa usia bukan merupakan faktor penyebab utama peningkatan dan penurunan kadar gula darah dan DM tipe 2 tidak berhubungan dengan hormon estradiol.
\end{abstract}

Kata kunci: Diabetes melitus tipe 2, hormon, kadar estradiol

Corresponding Author: David Lionardi, Master Program of Biomedical Sciences, Universitas Prima Indonesia, Medan, North Sumatera, Indonesia, Email: lionardidavid@gmail.com 


\section{Introduction}

Type 2 Diabetes mellitus (type 2 DM) is a metabolic disorder characterized by an increase in blood sugar caused by decreased insulin secretion by pancreatic beta cells and/or impaired insulin function (insulin resistance). ${ }^{1,2}$ Type 2 Diabetes mellitus patients require longterm care and treatment to prolong life and improve the quality of life. ${ }^{3}$

In the Diabetes Atlas 2019 (International Diabetes Federation), it is recorded that there were 463 million populations with type 2 DM in the world in 2019, which is predicted to increase with time. It is estimated that in 2045, the number of type 2 DM cases would reach 629 million populations. This disease ranks the seventh leading cause of death in developing countries. ${ }^{4}$

Almost $80 \%$ of diabetics live in low and middle income countries. Based on IDF data in 2017, Indonesia ranks sixth globally as a country with the highest prevalence of diabetes after China, India, the United States, Brazil, and Mexico with 10 million people living with diabetes in 2015. The prevalence of people with diabetes in Indonesia tends to increase from 5.7\% in 2007 to $6.9 \%$ in 2013 . With this trend, it is estimated that in 2045 , there will be 16.7 million diabetics in the age group of 20-79 years in Indonesia. $4,5,6$

Type 2 DM links to the estrogen hormones, or $17 \beta$-estradiol (estradiol). During the reproductive age, where the production of this hormone is done continuously, estradiol protects beta pancreas cells from apoptosis and prevents insulin deficiency. This explains the lower prevalence of diabetes in women, showing the protective role of female sex steroids protect against pancreatic $\beta$-cell injury when compared to male hormones. ${ }^{7}$

Estrogen is a carbon steroid hormone 18 that consists of estrone (E1), estradiol (E2), and estriol (E3). The most potent estrogen is estradiol, which is a product of the ovary. Estron is the primary product of androstenedione conversion and can also be produced in the liver through the transformation of $17 \beta$-hydroxysteroid dehydrogenases from estradiol. Estradiol is mainly seen in the bound form with a carrier protein in the bloodstream. Albumin carries about $60 \%$ of estradiol, while globulin binds $38 \%$ of estradiol and the remaining $2 \%$ is free in the bloodstream. ${ }^{8}$

A study that was performed on rats given estradiol-deficient or estradiol-resistant with impaired target aromatase (ArKO) or ER $\alpha$
( $\alpha$ ERKO) also demonstrated that, in both sexes, ArKO -/-, mice are susceptible to $\beta$-cell apoptosis and responsive to insulin-deficient diabetes after exposure to acute stress oxidative with streptozotocin. In mice, estradiol treatment saves streptozotocin-induced $\beta$ cell apoptosis, helps maintain insulin production, and prevents diabetes. ${ }^{7,9}$

In vitro, in rat pancreas and $\beta$ cells exposed to stress oxidative, estradiol inhibits apoptosis and protects insulin secretion. Estradiol protection is lost in $\beta$ cells and treated with ER $\alpha$ antagonists and in $\alpha$ ERKO. Therefore, $\alpha$ ERKO mice are no longer protected by estradiol and show sexspecific susceptibility to oxidative damage, accelerating $\beta$ cell apoptosis, and leading to insulin deficiency diabetes. The tendency of insulin insufficiency can be replicated in mice by pharmacological inhibition of $E R \alpha$ using fenantagonis tamoxi. This previous study showed that estradiol, which acts through $\mathrm{ER} \alpha$, protects B cells from oxidative injury, and prevents diabetes in mice of both sexes. ${ }^{7}$

With this in mind, this study aims to explore the possibility of hormone estradiol remains protective and prevents apoptosis in the pancreatic beta, or vice versa, and the disruption of the estradiol hormone.suffering from type 2 diabetes mellitus in people living with type 2 diabetes.

\section{Methods}

This analytical study was carried out at Royal Prima Hospital Medan (North Sumatera, Indonesia) in September 2019 to assess the relationship of type 2 Diabetes Mellitus with the hormone estradiol in women of reproductive age and approved by the Ethics Committee (038/ KEPK/UNPRI/IX/2019).

Accidental sampling was applied and resulting in 20 subjects with type 2 diabetes mellitus at Royal Prima Hospital as subjects. The patients were given informed consent regarding this study. After they gave consent, blood collection in 20 patients was be carried out simultaneously at PATHLAB Medan after fasting for 10-12 hours to check fasting blood sugar levels and estradiol hormone levels.

Inclusion criteria used were women aged 4050 years with diabetes mellitus, outpatients or inpatients. Exclusion criteria were patients with hypertension, autoimmune diseases, cancer, and other comorbidities.

All statistical analyses were performed using 
Table 1 Characteristics of Type 2 DM Patients at Royal Prima Hospital

\begin{tabular}{cc}
\hline Age Group & $\begin{array}{c}\text { Frequency } \\
(\mathbf{n = 2 0})\end{array}$ \\
\hline $40-45$ years & 6 \\
$46-50$ years & 14 \\
\hline
\end{tabular}

SPSS version 20.0. Significant results were reflected with a P-value of less than 0.05 . Before analysis, data were analyzed for normality using the Shapiro-Wilk test and when the distribution was normal, the average difference of the two numeric variables was tested using the $t$-independent test. In order to assess the relationship between the independent variable and the dependent variable, the correlation test was used.

\section{Results}

The subjects of this study were 20 women with type 2 diabetes mellitus, with the majority were $46-50$ years $(\mathrm{n}=14)$ with the remaining subjects $(30 \%)$ aged $40-45$ years (Table 1$)$.

An analysis of data normality using the Shapiro-Wilk test was conducted, showing that the estradiol levels were normally distributed. Thus, analysis was continued using the t-independent test (Table 2).

The average estradiol levels in the younger age group (40-45 years) were lower than those in the older age group (46-50 years). From the results of the T-Independent test analysis, it was revealed that the $\mathrm{p}$-value was $<0.05$ ( $\mathrm{p}$-value $=0.000$ ), showing a statistically significant difference between the two groups.

In contrast to the estradiol level, the blood sugar level test results did not demonstrate a statistically different blood sugar level between the two age group as seen in Table 3. This was apparent from the resulting p-value of 0.113 (p-value >0.05).

The analysis was then continued by assessing the relationship between the blood sugar level $(173.75 \pm 39.26)$ and estradiol level $(665.03 \pm 305.21)$ in blood using the correlation test, resulting a P-value of 0.240 . This showed that there was no statistically significant correlation between in the blood sugar level and estradiol level although the correlation coefficient of 0.275 showed a weak correlation between the blood sugar level and estradiol level, albeit insignificant.

\section{Discussion}

Type 2 DM were more prevalent in patients aged 46-50 years, which comprised $70 \%$ in this study, with the remaining subjects aged 40-45. The blood sugar level was higher in patients aged 46-50 (184.93 \pm 31.39$)$ than in those who were 40-45 years old $(147.67 \pm 46.12)$. Likewise, the estradiol level among those who were over 46 years old was higher $(792.80 \pm 275.15)$ than those under 45 years $(366.90 \pm 69.14)$.

These findings were in line with a study conducted by Heianza et al., ${ }^{10}$ which stated that a person aged $\geq 45$ years has an increased risk of developing type $2 \mathrm{DM}$ due to a reduced number of productive $\beta$ cells caused by decreased body function. ${ }^{11}$

Age also has a close connection with the

Table 2 Estradiol Level by Age Group

\begin{tabular}{ccc}
\hline Age Group & $\begin{array}{c}\text { Estradiol Level (pmol/l) } \\
{[\text { Mean } \pm \text { SD] }}\end{array}$ & p-value \\
\hline $40-45$ years & $366.90 \pm 69.14$ & 0.000 \\
$46-50$ years & $792.80 \pm 275.15$ & \\
\hline
\end{tabular}

Table 3 Blood Sugar Level by Age Group

\begin{tabular}{ccc}
\hline Age Group & $\begin{array}{c}\text { Blood Sugar Level } \\
\text { (pmol/1) } \\
{[\text { Mean } \pm \text { SD] }}\end{array}$ & p-value \\
\hline $40-45$ years & $147.67 \pm 46.12$ & 0.113 \\
$46-50$ years & $184.93 \pm 31.39$ & 0 \\
\hline
\end{tabular}


increase and decrease of the hormone estradiol. This complies with a study conducted by Puspita et al., stating that the younger the age, the lower the hormone estradiol level as this hormone is responsible for the role of preparing the uterus for implantation and fetal growth. ${ }^{12}$ This is also supported by the theory stating that there is excessive production of androgens by the ovaries and adrenal glands in premenopausal age, which are then converted into estrogen by the aromatase enzyme found in adipose and fat tissue. This condition becomes the reason estradiol hormone increases in premenopausal age. ${ }^{13}$ The results of these previous studies and theories are in line with our results, as listed in Table 2, showing that at the age of 40-45 years, the hormone estradiol level is lower than in the age of 46-50.

However, when viewed from blood sugar levels, age does not directly contribute to blood sugar level. As can be seen in Table 3, there is no significant difference between the two age groups. This is consistent with a study conducted by Chentli et al., ${ }^{14}$ which suggested that when people get older, a decrease in muscle mass will be observed. Therefore, the older people may experience a loss of muscle strength, which may contribute indirectly to reduced ability in doing normal activities. Reduced physical activities and muscle mass may cause a build-up of fat in the body, which then lead to insulin resistance, increasing the weight of the individual. ${ }^{15}$ Overweight individuals may experience changes in the glucose levels of glucagon plasma and insulin. They may face disruption in the development of insulin resistance, and the resulting diabetes is caused more by changes in body composition than aging. ${ }^{9,16,17}$

In type $2 \mathrm{DM}$, the presence of hormone estradiol plays a role as a pancreatic beta protector from apoptosis. However, in this study, the relationship between the hormone estradiol and type $2 \mathrm{DM}$ is relatively weak. This correlation is increasingly supported by Gyllenhammer et al., who declares that physical activities have a close connection with the increase and decrease in estradiol levels in reproductive age. When a person rarely does physical activities, the level of estradiol will be higher for the individual. ${ }^{17,18}$

In addition to physical activities, the relationship between diet and hormone estradiol is also quite strong. It is stated in a study conducted by Sapre et al. ${ }^{19}$ that diet affects the synthesis of hormone estradiol. It is recommended to eat foods high in fiber to maintain the stability of hormone estradiol. Many factors can also affect estradiol levels, including the lifestyle factors such as smoking. ${ }^{20}$

\section{References}

1. Fatimah RN. Diabetes tipe 2. J Majority 2015;4(5):93-4.

2. Zhao Y, Xu G, Wu W, Yi X. Type 2 diabetes mellitus disease, diagnosis and treatment. J Diabetes Metab. 2015;6(5):1-2.

3. Gao Y, Wang Y, Zhai X, He Y, Chen R, Zhou J, et al. Publication trends of research on diabetes mellitus and T cells (1997 \pm 2016$)$ : A 20-year bibliometric study. 2017;12(9):e0184869.

4. IDF. Diabetes Atlas Ninth edition 2019. Individual, social and economic impacts. Brussels: IDF Advocacy Guide; 2019.

5. Kaur H, Kochar R. Stress and diabetes mellitus. Int J Health Sci Res. 2017; 7 (7):26572.

6. Wu Y, Ding Y, Tanaka Y, Zhang W. Risk factors contributing to type 2 diabetes and recent advances in the treatment and prevention. Int J Med Sci. 2014;11:1185-7.

7. Gupte AA, Pownal HJ, Hamilton DJ. Estrogen: an emerging regulator of insulin action and mitochondrial function. J Diabetes Res. 2015;2015:916585.

8. Hamad MNM, Elbadri FA. Estrogen a wonderful hormone. Latvia: Lambert Academic Publishing; 2017.

9. Durruty P, Sanzana M, Sanhueza L. Pathogenesis of type 2 diabetes mellitus, type 2 diabetes - from pathophysiology to modern management. IntechOpen. 2019;2019:1-18.

10. Heianza Y, Arase Y, Kodama S, Hsieh SH, Tsuji $\mathrm{H}$, Saito K, et al. Effect of postmenopausal status and age at menopause on type 2 diabetes and prediabetes in Japanese individuals: Toranomon Hospital Health Management Center Study 17 (TOPICS 17). Diabetes Care. 2013;36(12):4007-14.

11. Olokoba AB, Obateru OA, Olokoba LB. Type 2 diabetes mellitus: a review of current trends. Oman Med J. 2017;27(4):269-70.

12. Puspita EM, Siregar MFG, Adenin I. Correlation of estradiol serum levels with classification of osteoporosis risk OSTA (Osteoporosis Self-Assessment Tools for Asian) in menopause women. Bali Med J. 2017;6(1):52-4.

13. ZRT Laboratory. Understanding hormone highs and lows. Beaverton, Oregon: ZRTLaboratory; 2017.

14. Chentli F, Azzoug S, Mahgoun S. Diabetes 
mellitus in elderly. Indian J Endocr Metab. 2015;19:744-52.

15. Fareed M, Salam N, Khoja AT, Mahmoud MA, Ahamed M. Life style related risk factors of type 2 diabetes mellitus and its increased prevalence in Saudi Arabia: a brief review. Int J Med Res Health Sci. 2017;6(3):125-8.

16. American Diabetes Association. Older adults: standards of medical care in diabetes. Diabetes Care. 2018;41(1):199-24.

17. Chatterjee S, Khunti K, Davies MJ. Type 2 diabetes. Lancet. 2017;389(10085):1-4.
18. Gyllenhammer LE, Vanni AK, Byrd-Williams CE, Kalan M, Bernstein L, Davis JN. Objective habitual physical activity and estradiol levels in obese latina adolescents. J Phys Act Health. 2013; 10(5):727-31.

19. Sapre S, Thakur R. Lifestyle and dietary factors determine age at natural menopause. J Midlife Health. 2014;5(1):3-5.

20. Kaku K. Pathophysiology of type 2 diabetes and its treatment policy. JMAJ. 2010;53(1):41-4. 